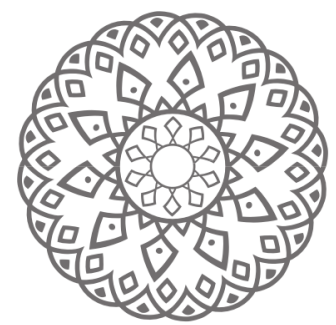

\title{
Legitimacy ON INTER-Faith Marriages: An Analysis of the Role of Religious Councils on the Legal Policy in Indonesia
}

\author{
Rosdiana, Ummu Hanah Yusuf Saumin, \& Masayu Mashita Maisarah
}

\begin{abstract}
The legal vacuum for of inter-faith marriage is one of the unresolved issues in Indonesia, especially with regard to civil rights. Indonesia’s Marriage Law No. 1 of 1974 has not accommodated the legal policy of marriage between different religions. Moreover, there are some different views between religious leaders on the permissibility of the inter-faith marriage. This study attempts to analyse the relations between Indonesia's Religious Councils and the legal policies on inter-faith marriages. Data was collected through observation and semi-structured interviews with the representative of Indonesia's religious councils from six religions. This article finds that Indonesia's Religious Councils have no role by any means in the formation of legal policies related to inter-faith marriage in Indonesia since the Marriage Law had been created before the Religious Councils established. Regarding the legitimacy of inter-faith marriage, the religious leaders offered conflicting statements. Several religious leaders still decided to stay with the prohibition of interfaith marriage based on the popular religious traditions and the constitutional realm. Albeit religious leaders favour or disfavour inter-faith marriage, the practice is still widely flourished and rapidly increased. This observable fact should be an important reason for the Constitutional Court either to grant or deny the practical of inter-faith marriage in Indonesia.
\end{abstract}

Keywords: Inter-faith Marriages, Religious Councils, Legal Policies, Indonesia 
Abstrak: Kokosongan landasan hukum dalam kasus perkawinan beda agama adalah salah satu masalah yang belum terselesaikan di Indonesia. Hal ini terkait dengan hak-hak sipil. Undang-Undang Perkawinan Indonesia No. 1 Tahun 1974 tidak mengakomodasi kebijakan hukum perkawinan dari berbagai agama. Selain itu, ada perbedaan pandangan antara para pemimpin agama tentang diizinkannya pasangan dari agama yang berbeda, misalnya dalam hal peninjauan materi Pasal 2 ayat (1) UU Perkawinan. Oleh karena itu, penelitian ini berupaya untuk menganalisis hubungan antara Dewan Agama Indonesia dan kebijakan hukum tentang pernikahan antar agama. Data dikumpulkan melalui observasi dan wawancara semi-terstruktur dengan perwakilan dari Dewan Agama Indonesia dari lima agama yang diakui di Indonesia. Artikel ini menemukan bahwa Dewan Agama Indonesia tidak memiliki peran dengan cara apa pun dalam pembentukan kebijakan hukum terkait dengan pernikahan beda agama di Indonesia, karena UU Perkawinan telah dibuat sebelum Dewan Agama didirikan. Dalam topik legitimasi pernikahan lintas agama, para pemimpin agama menyatakan pernyataan yang bertentangan. Sejumlah pemimpin agama masih memutuskan untuk tetap dengan larangan pernikahan antar agama berdasarkan tradisi keagamaan populer dan ranah konstitusional; sementara beberapa lainnya memberikan sebaliknya. Meskipun para pemimpin agama mendukung atau tidak menyukai pernikahan antaragama, praktik ini masih terjadi bahkan meningkat pesat. Fakta ini harus menjadi alasan penting bagi Mahkamah Konstitusi untuk memberikan atau menolak praktik pernikahan antaragama di Indonesia.

Kata kunci: perkawinan antaragama, Dewan Agama, Kebijakan Hukum di Indonesia 


\section{Introduction}

The phenomenon of inter-faith marriage in Indonesia cannot be separated from pluralism issues. From the results of the Central Bureau of Statistics (BPS) census in 2010, it shows that from 237.641.326 people in Indonesia, there are $87.18 \%$ are Muslims; $6.96 \%$ are Christian; 2.91\% are Catholic; 1.69\% are Hindus; 0.72\% are Buddhists; 0.05\% are Confucian; and the remaining $0.13 \%$ others. Although Muslims is a majority, yet inter-faith marriage occurs least among Muslims (Aini, 2008: 669-705).

Inter-faith marriage becomes an inevitable social phenomenon in which religious doctrines are transformed and incorporated into social and cultural contexts. For instance, in spite of many societies and religions strongly stereotyping and even prohibiting inter-faith marriage, the practice of inter-faith marriage has widely flourished and rapidly increased. Comprehensively has been specified by Ahmad Nurcholish (2015) who researches with the same issues from 2005 to 2015 . His finding shows that by number, from total 638 couples of inter-faith marriage, the practitioners are dominated by Muslim-Christian (48\%), Muslim-Catholic (42\%), and the remaining 10\% are Muslim-Hindu, Muslim-Buddhist, Muslim-Confucian, Christian-Buddhist, ChristianHindu and Christian-Confucian. From the geographical aspect, the implementation of interfaith marriage occurs mostly in West Java (20\%), Central Java (19\%), Yogyakarta (15\%), East Java (14\%), Bali (14\%), South Sulawesi (10\%), East Kalimantan (6\%), Sumatra (1\%), and East Nusa Tenggara (1\%) (Nurcholish, 2015: 139). These numbers indicate that the practice of inter-faith marriage in Indonesia continues to increase year by year and spread almost to the corners of the country.

Concerning this finding, the problem that arises from the Indonesian cases is that Indonesia's Marriage Law (Law No. 1 the Year 1974) has not accommodated the legal policy of marriage from different religions. Some scholars like Ratno Lukito (2008) and Mark Cammack (2009) also stated that the occurrence of legal vacuum for the practitioners of inter-faith marriage is one of the unresolved issues in Indonesia, especially with regard to the civil rights. On the other hand, religious leaders in Indonesia provide dissimilar statement toward this issue. Testifying this statement, Muchaddam (2014: 11-12) and Ahmad Nurcholish (2015: 141) conducted a study, which shows that 
the religious leaders in Indonesia have different views on the material review of Article 2 paragraph (1) of the Marriage Law, which is closely related to religious law.

Table 1.1 Pro-Cons of Material Review Article 2 (1) of the Marriage Law

\begin{tabular}{|ll|}
\hline \multicolumn{1}{|c|}{ Pro } & \multicolumn{1}{c|}{ Cons } \\
\hline $\begin{array}{l}\text { Indonesian Council of Islamic } \\
\text { Scholars (MUI) }\end{array}$ & $\begin{array}{l}\text { Indonesian Conference on Religion } \\
\text { and Peace (ICRP) }\end{array}$ \\
\hline Front Pembela Islam (FPI) & $\begin{array}{l}\text { Human Rights Working Group } \\
\text { (HRWG) Indonesia }\end{array}$ \\
\hline $\begin{array}{l}\text { Central Leadership of } \\
\text { Muhammadiyah }\end{array}$ & National Commission for Women \\
\hline $\begin{array}{l}\text { Central Leadership of Nahdhatul } \\
\text { Ulama }\end{array}$ & $\begin{array}{l}\text { National Commission of Human } \\
\text { Rights }\end{array}$ \\
\hline $\begin{array}{l}\text { Hindu Dharma Council of } \\
\text { Indonesia (PHDI) }\end{array}$ & \begin{tabular}{l} 
Indonesian Church Association (PGI) \\
\cline { 2 - 2 }
\end{tabular} \\
\cline { 2 - 2 } & $\begin{array}{l}\text { Indonesian Bishops Conference (KWI) } \\
\text { Guardianship of the Indonesian } \\
\text { Buddhist Community (WALUBI) }\end{array}$ \\
\cline { 2 - 2 } & $\begin{array}{l}\text { Supreme Council for Confucian } \\
\text { Religion in Indonesia (MATAKIN) }\end{array}$ \\
\hline
\end{tabular}

Table 1.1 demonstrates two different opinions on the legality of inter-faith marriage in Indonesia. In one hand, the pro's argued that the religious traditions had prohibited the practice of interfaith marriage with no exception; while on the other hand, the con's assumed that inter-faith marriage is part of human rights. Universal human rights have maintained that every human being has a right to build a family regardless of religious consideration. With these two different arguments, some questions remain interesting to ask: what is the role of Religious Council son influencing the policy of inter-faith marriage in Indonesia? And to what extent does the participation gives a contribution in implementing the inter-faith marriage policy? This paper deals with the responsibility of Indonesia's Religious Councils and the legal policies on inter-faith marriage. To begin with, this paper will discuss the state management on inter-faith marriage from a 
historical view, followed by opinions of the Religious Councils towards inter-faith marriage, and ended up with the role of Religious Councils' opinion on inter-faith marriage legal policy.

\section{State Management on Marriages}

A state has a function to protect its civilian (Lipson, 41). This statement shows that in order to achieve protection and justice, the state must be able to act as a mediator who can provide solutions to the conflicts that lead to social disintegration. In other words, the state indirectly needs to involve itself in dealing with the religious activities of its citizens to realize this order. For the Indonesian cases, the statement has been posit in the fourth paragraph of the preamble of the 1945 Constitution and several other forms of regulation, such as Article 29 of the 1945 Constitution and its interpretation, which states that the government is obliged to regulate religious life in Indonesia.

According to Abdillah, the relationship between religion and state both in the concept of the constitutional system and reality remains in intersectional form, which means not fully integrated and not completely separated (in http://graduate.uinjkt.ac.id/index.php/12kolom-direktur/11-hubungan-agama-dan-negara). In this relation, there are some religious aspects that cross the threshold of the country, and there are also some aspects of the state that require the legitimacy of religion. Hence, it is accurate to say that Indonesia is neither a secular nor a religious state; rather, it is based on Pancasila (Syadzali, 1993).

The state involvement in religious affairs is very considerable. Indonesia has a specific ministry, which deals with religious affairs called the Ministry of Religious Affairs (Kementerian Agama). Moreover, several regulations concerning Islam have been issued by the government under New Order to accommodate Muslim interests, such as Waqf Regulation in 1977, Marriage Law of 1974, Religious Court Act in 1989 and the Compilation of Islamic Law (Kompilasi Hukum Islam) in1991. In this regard, the Compilation is the main source for solving marital issues today due to some vagueness found in Marriage Law of 1974 (Widiati, 2012: 858-865).

Insofar as the marriage law is concerned, Indonesia has not implemented a unified marriage law since its independence. On the 
contrary, there were several marriage laws enforced at the time. The Islamic marriage law regulates the marriage among all Indonesian Muslims; the Civil Code regulates the marriage among persons who are subject to Western law, the Ordinance of 1933 for the marriage of Indonesian Christians; and the customary law (bukum adat) for those who are neither Muslims nor Christians (Subekti, 1973: 9-15). This practice had been recognized and implemented by the Dutch colonial and kept in force by the government of the newly Republic of Indonesia more or less three decades later. This variety of law leads the government to submit a new marriage bill to the Parliament on 31 July 1973 and, after long and heated debate and revision, this bill was then passed by the Parliament on 22 December 1973, and signed by President Soeharto on 2 January 1974 as the Indonesian Marriage Law No. 1 of 1974 (Azzra, 2003: 76-95). However, it does not mean that this law has regulated all aspects related to marriage, such as the marriage of different religions.

Previously, the inter-faith marriage was recognized as 'mixedmarriage' which arranged for the first time in the Regeling op de gemengde Huwelijken, Staatblad 1898 No. 158, before the birth of the Marriage Law No. 1 of 1974 . One of the provisions in the regulations of mixed-marriage is in the Article 7 paragraph (2) which stipulates that'the differences in religion, class, population or origin cannot be a barrier to marital sustainability (Purwaharsanto, 1992: 10-13). From this statement, inter-faith marriage, according to some experts and legal practitioners can be found in three views:

(1) Inter-faith marriage cannot be justified and constitutes an infringement of the marriage as stated in the Article 2 paragraph (1): 'marriage is legitimate if it is conducted according to the laws of respective religions and beliefs of the parties involved.' With this article, marriage from different religions is considered invalid and void by law.

(2) Inter-faith marriage is permissible, valid and can be carried out because it is covered in a mixed-marriage, as set in Article 57 of the Marriage Law, i.e. two persons in Indonesia are subject to different laws. According to this second view, the chapter not only governs marriage between two persons of different nationalities but also regulates the marriage between two persons of different religions. 
(3) The marriage law does not regulate inter-faith marriage matters. Therefore, when referring to Article 66 of the Marriage Law, which emphasizes that other rules governing marriage, to the extent provided for in this law, shall be declared null and void. However, since marriage legislation has not been regulated, then the old regulations can be re-enacted, so the issue of marriage of different religions should be guided by mixed-marriage regulations (Trisnaningsih, 2007: 57).

Indeed, Indonesia marriage laws prohibited the inter-faith marriage, but the reality shows otherwise. Albeit religious leaders disfavor inter-faith marriage, many would-be intermarried couples will always find ways to perform the inter-faith marriage. The implementations of inter-faith marriages are still completed through four popular ways: (1) conducting such a marriage overseas in a country where inter-faith marriage is legal, such as Singapore and Australia; (2) performing weddings under social organizations, such as Paramadina Foundation and The Wahid Institute; (3) committing hypocritical religious conversion prior to marriage solemnization, and reconversion post the marriage contract in order to meet formally all legal conditions; and (4) look for a court decisions (Aini, 2015 : 4345). Concerning the last method, the intermarried couple is required to register their marriage at the Civil Registry Office (Kantor Catatan Sipil, KCS) since there is no governmental office to acknowledge interfaith marriages. In the case of an unregistered marriage, the women have no legal right to claim alimony at the time of divorce and children born of such marriages have no right of inheritance from their parents.

\section{Religious Traditions on Inter-faith Marriages}

Since Indonesia composed by multi-religious, apart from providing religious services and religious education, the state is responsible for fostering inter-religious harmony. In the beginning, the government issued a Circular Letter of the Minister of Home Affairs No.477/74054/1978 as recognition on several religions in Indonesia, namely Islam, Catholicism, Christianity/Protestantism, Hinduism, Buddhism and Confucianism (Hidayat and Gaus, 2001: 225. The recognition is manifested primarily in the form of official recognition for certain religious institutions, as well as the adoption of religious values and norms in the national 
system and public policy making, such as the legislation of certain religious (Islamic) laws into national law. The state also recognizes the existence of political parties and mass organizations with a religionbased. In addition, the government established religious institutions, such as Indonesia Council of Islamic Scholars (MUI), Indonesian Church Association (PGI), Indonesian Bishops Conference (KWI), Hindu Dharma Council of Indonesia (PHDI), Guardianship of the Indonesian Buddhist Community (WALUBI), and Supreme Council for Confucian Religion in Indonesia (MATAKIN).

On the issues of interfaith marriage, this following section will describe the law addressed by each religious tradition.

\section{Islamic's Perspective on Inter-faith Marriages}

Marriage (nikah) in Islam is a sacred covenant, essential to realizing the "essence of Islam. " However, in form, Islamic marriage is a basic civil contract involving an offer of the woman by herself or her guardian and acceptance by the man who pays a dower as consideration (Sedgwick: 88.). Though shari'a contains certain default rules concerning maintenance, inheritance, and divorce, the contracting parties are free to negotiate the terms of their union specifically. (Kuzman, 1998: 152-153). While some scholars have begun to argue for new interpretations of inter-faith marriage rules, the principal schools of Islamic jurisprudence all share the same basic conception of the marital relationship. This conception adheres to classical sharia regulations: "a Muslim man may marry a Christian or Jewish woman but no other unbeliever; a Muslim woman may not marry a non-Muslim under any circumstances (Q.S. 2: 221; 5; 5: 5: 60). Traditional Muslim scholars and clerics contend that the Qur'an both directly and inferentially restricts marriage outside the faith. However, even a casual reading of the Qur'an reveals that its passages leave room for interpretation (Rahman, 1980: 451-456).

\section{Catholic \& Protestant's Perspective on Inter-faith Marriages}

Prior to the Second Vatican Council (Vatican II) in the 1960s, the Catholic Church strongly opposed interfaith marriage (Tirimana, 127). In the Catholic Church, marriage was considered to be a sacred 
bond that would be strengthened by the spouses' shared faith. Several decades ago, interfaith weddings took place outside of the parish church. Additionally, the interfaith couple was forced to promise that, if they had a family, the children would be raised as Catholics. Some Catholics who married outside of the faith risked excommunication from the Church (Davidson, 1999: 14-16).

Today's Catholics do not face such harsh consequences when marrying someone of a different religion. Since Vatican II, the Church continues to discourage interfaith marriage but has become more accepting of it. Interfaith marriages can now take place in a Catholic church. Although the Church acknowledges and respects the nonCatholic spouse's religious beliefs, it believes the religious upbringing of the couple's children is primarily the duty of the Catholic spouse (Pivonka, 2010: 9).

The Catholic Church used to require those who were not Catholic to sign a document promising that the children would be raised Catholic. This was true also when Catholics married other Christians. That is no longer the case. Canon Law today requires that the Catholic parties promise that they will not give up their faith due to the marriage and that they will do "what is in their power" to share the Catholic faith with their children.

\section{Hindu's Perspective on Inter-faith Marriages}

Hinduism is the common name given to a multitude of religious sects and practices in India, which are based on six schools of philosophy, other than the common Sacred Scriptures; there is no central authority or official policy which binds all Hindus. What is central, however, is the understanding that marriage is a sacred relationship between two souls and fulfillment of four aims of human life, duty, wealth, sensuous pleasures and salvation.

There are two other fundamental beliefs that govern the Hindu understanding of marriage: the first is that the marriage relationship extends beyond one's life across seven or more lives during which the couple help each other to progress spiritually. The second is that the bride and the bridegroom are divinities. Thus, in a traditional ceremony, which is conducted by a priest or a Brahmin, the bride is first married 
to the Gods and then placed under the bridegroom's protection as a gift from the Gods.

While inter-faith marriages would be strongly discouraged in orthodox Hinduism predominantly due to cultural reasons and social conventions, there is no one globally binding position on inter-faith marriage. However, a broad Hindu understanding of inter-faith marriage could be based on two principles, which are inherent to Hinduism. Firstly, the breadth of Hindu religion which can comfortably accommodate any religious faith and practice to its sphere of religion; and secondly, its fundamental humanism which highlights the equality of all human beings regardless of caste, colour and creed. Based on these two principles, it can be said that in the modern practice of the faith, Hindus do not oppose to an inter-faith marriage provided the life-long bond in marriage is in perspective and due consideration is given to all the practicalities of modern life which may facilitate such a relationship. (Apte, 1978).

\section{Buddhist's Perspective on Inter-faith Marriages}

The Buddhist position on marriage is founded on the understanding that the union of male and female is an intrinsic characteristic common to all living beings. The institution of marriage is considered both an individual concern and social convention, which is necessary to distinguish human beings from animal life. However, marriage is not constituted in Buddhism as a religious duty, which is guided by regulations. Rather, the advice is given to promote wellbeing and happiness between a man and a woman to lead a lifelong relationship founded on shared responsibilities, fidelity and loyalty.

Buddhist monks do not marry and are celibate. They do not attend marriage ceremonies and therefore do not preside at wedding ceremonies - they may offer blessings to couples on request on occasion other than the marriage ceremony. Buddhist do not have an official marriage liturgy or ceremony, and regional customs and practiceswhich are farmed within the acts of paying homage to Lord Buddha, seeking refuge in the Triple Gem (Buddha, Dhamma and Sanga) and reciting the Five Precepts - provide a wide range of ceremonial elements and activities 
Buddhism allows inter-faith marriages. Buddhism maintains the teaching that every human being has the freedom to follow the religion of one's choice and enter into marriage with a partner of one's choice. With the primary emphasis being on the life-long bond in marriage and the compatibility of the partners, which may facilitate such a relationship, Buddhism does not oppose a Buddhist marrying a person of another religion. Understanding, respect and mutuality which results from the compatibility of the partners - are seen as the ingredients that would enable the Buddhist and non-Buddhist partners to render equal status to their religions and fulfill marital, social and religious duties and obligations (Clarke and Thompson, 2005).

\section{Confucian's Perspective on Inter-faith Marriages}

From the point of view of Confucian philosophy, one of the purposes of marriage is the cultivation of virtue. The Chinese have seen that marriage should be founded on love since the concept of monogamy is rooted in their mindset. Therefore, to the Confucian, marriage is an important significance both in the family and in society.

Although inter-faith marriages are not forbidden in Confucianism, it does not mean that they are liberated without rules. In the Book of Rites ( $\mathrm{Li} \mathrm{Ji)}$ ), it stipulates, "The ceremony of marriage was intended to be a bond of love between two (families of different) surnames, with a view, in its retrospective character, to secure the services in the ancestral temple, and in its prospective character, to secure the continuance of the family line (Hwan I)." Also, "The Master said: A man in taking a wife does not take one of the same surnames with himself:--to show broadly the distinction (to be maintained between man and wife) (Fang Ki)."

Based on these verses, Tjay Ing (1998) assumed that there are two things that need to be emphasized. Firstly, to the Confucian, conducting marriage with a one clan couple is forbidden; the marriage was intended to be a bond of love between two families of different surnames, to secure the continuance of the family line. Secondly, the Confucian are not be on familiar terms with the inter-faith marriage. One condition that should be obeyed by the would-be married couple is the confession of faith. In Article 3, paragraph (4) sub (a) mentioned, "The confession of faith is mandatory for prospective brides who have not received the confirmation." Yet in sub (b) stated, "If the affirmation is 
not possible, then the Confucian's leader can take sagacity (Ing: 1986: 37)". The last paragraph illustrates that there does not impede for the Confucians to marry other believers, but neither is recommended nor expected. This expression is based on the provisions of the Book of Holy Word (Lun Yu-Lun Gi), Chapter XV Article 40, which writes the words of the Prophet, "if different religious paths, do not argue (Ing: 1986; 37).”

\section{The Religious Councils' opinion on Inter-Faith Marriages}

Majority of the religious traditions had prohibited inter-faith marriage with the same argument, that happiness is the core intention of marriage, which cannot easily be reached by a couple from different religious traditions. However, on the issues of inter-faith marriage in Indonesia, religious institutions have a dissimilar attitude. The following section will analyze the inter-faith marriage addressed by Religious Councils.

Asked about their stance on inter-faith marriage as part of a judicial review hearing at the Constitutional Court, the religious leaders offered various statements. From the Islamist's side, the MUI strictly banned the inter-faith married. Although in the Quranic texts and the interpretations on verses [2]:221, [5]:5, [60]:10 varies, but for the benefit of the people this practice must be avoided and not legalized. Hasanuddin AF and Asrorun Niam Sholeh as the Chairman and the secretary of the fatwa commission explicitly express their views on inter-faith marriages.

"For the past twelve years, the MUI's stance has not changed on this issue, since it will give a big impact on the community. Regarding the Muslims who perform this practice, MUI decided not to interfere, since it is their choice. But the MUI remains in its view that it is haram to marry a person with different religions (Niam and Hasanudin, interview October 2017)."

Similar to MUI, from the Hindu's side, I Nengah Dana and Yanto Jaya as the representation of PHDI dissent the practice of inter-faith marriage.

"Marriage is formalized with a rite called Wiwaha Samskara led by a cleric, so would-be married couple both should be Hindu. The Hinduism does not recognize inter-faith marriage since it is susceptible 
to the conversion of religion. Therefore, this practice shunned by Hinduism (Dana and Jaya, Intervied 2017).”

Unlike MUI and PHDI, the Christians, Buddhists and Confucians' side permitted the inter-faith marriage. On the Christian's view, Father Siswantoko and Father Benny Susetyo as representatives of KWI stated that there is no prohibition at all related to inter-faith marriages. This statement is a contrast to same-sex marriages, in which the Catholic Church strongly banned. Both Siswantoko and Benny have experience in giving religious blessing to couples from different religions.

"The church has accommodated this practice since they cannot deny the existence of inter-faith marriage practices among Catholics. Although KWI does not prohibit this practice, the attitude of the Catholic Church remains firm that people who want to establish an inter-faith marriage in the Catholic Church must follow the rules in accordance with what has been outlined by the Church. They must go through a series of wedding courses, then manage a letter of dispensation from the Church stating that they are allowed to marry even though different religions. In Catholic itself, there are differences between inter-faith marriages and inter-church weddings. The former was a different religion at all; while the latter was the difference between Catholic and Protestant but equally believed in the Church. So with this reality, it becomes a necessity of the plural society to accept this practice, since marriage is essential to human life and that the state should not interfere in people's pursuit of happiness. Nobody has the right to act against God's will (Siswantoko, Interview, August 25, 2017)."

In line with KWI, the PGI represented by Penrad Siagian and Gomar Gultom also stated that the marriage of different religions could not be rejected, because in fact they often found many couples who perform this practice. But because of the legal problems and civil registration, the would-be intermarried couples often fail to carry out their wedding. In this case, Penrad and Gomar stated,

"The state should protect all citizens without restricting their choice and will, since the multi-interpreted on Marriage Law have not allowed people who want to marry with different partners. PGI's attitude, in this case, is to encourage the government to immediately make a special regulation for couples who want to marry according to their choice (Siagian, interviewed August 30, 2017)”.

As well as PGI, Suhadi Sendjaja and Rusli as representatives of WALUBI mentioned, "The teachings of Buddha Gautama do not impose 
others to enter Buddhism. As for non-Buddhists who want to marry a partner from Buddhist, it is not forbidden (Sendjaja interviewed Oktober 17, 2017)." While from the side of MATAKIN, Uung Sendana and Budi Santoso explained,

"The Confucian religion does not forbid its people to married couples who are not Confucians. For Confucians, a forbidden marriage is a marriage with the same clan, while for marriage on inter-faith religion, is not regulated by the religion. Marriage should be conducted to achieve happiness and continue the bloodline. No political view, ethnicity, understanding, culture or even religion can stop it(Sendana and Santoso, interviewed October 09, 2017.)”

\section{Conclusion}

Legal policies on inter-faith marriage in the Indonesian context are still questioned between the ideals and reality of the constitutional realm. The disagreements among the organizers in responding to the inter-faith marriage are still happening, whereas the fulfillment of the right to marry is a part of human rights. In fact, the legal prohibition of inter-faith marriage and a variety of resistance from prominent leaders to inter-faith marriage cannot stop the practice of inter-faith marriage. This paper found that the Religious Councils have no role by any means in the formation of legal policies related to inter-faith marriage since the Marriage Law had been created before the Religious Councils established. Instead of limiting the cohabitation of inter-faith couples, albeit religious leaders favor or disfavor inter-faith marriage, the practice is still widely flourished and rapidly increased. This observable fact should be an important reason for the Constitutional Court either to grant or deny the practical of inter-faith marriage in Indonesia. The state has more responsibility in the form to clear the regulations or the actions of officials since Indonesia is based on law.

\section{References}

\section{Al-Qur'an}

Abdillah, Masykuri. "Hubungan Agama dan Negara dan Konteks Modernisasi Politik di Era Reformasi," in http://graduate.uinjkt.ac.id/index.php/12kolom-direktur/11-hubungan-agama-dan-negara.

Aini, Noryamin. "Inter-Religious Marriage and Inter-Generational Religious Mobility in Indonesia: Pattern, Rate and Correlates," Research Report. 
Jakarta: Sharia and Law Faculty, UIN Syarif Hidayatullah Jakarta, 2014.

Aini, Noryamin. "Inter-Religious Marriage from Socio-Historical Islamic Perspective," Brighm Young University Law Review, Vol. 2008, (3), (2008): 669-705.

Apte, Usha M. The Sacrament of Marriage in Hindu Society from Vedic Period to Dharmaśastras. Delhi: Balwant for Ajanta, 1978.

Azra, Azyumardi. "The Indonesian Marriage Law of 1974: An Institutionalization of Shari'a for Social Change," in Shari'a and Politics in Modern Indonesia, ed. Arskal Salim and Azyumardi Azra. Singapore: ISEAS, 2003.

Book I, KHÜ LÎ, or Summary of The Rules of Propriety.

Book XLI, HWAN Î or The Meaning of the Marriage Ceremony.

Book XXVII, FANG KÎ or Records of the Dykes.

Clarke, Steve., \& Thomson, Mel. Buddhism: A New Approach. London: Hodder \& Stoughton, 2005.

Davidson, J. D. "Outside the Church," Commonwealth, September 10, 1999.

Effendi, Djohan. "Jaminan Konstitusional bagi Kebebasan Beragama di Indonesia," in Komaruddin Hidayat \& Ahmad Gaus AF (ed.), Passing Over: Melintasi Batas Agama. Jakarta: Gramedia, 2001.

Esposito, John L. Women in Muslim Family Law. New York: Syracuse University Press, 2001.

Freshman, Patricia A. "Interfaith Marriage, Religious Orientation and Dyadic Adjustment," Master Thesis. Illinois: Northern Illinois University, 2010.

Kabir, Humayun. "Minorities in a Democracy," in Charles Kurtzman (ed.), Liberal Islam. London: Oxford University Press, 1998.

Lipson, Leslie. The Great Issues of Politic: An Introduction to Political Science. New York Prentice Hall.

Muchaddam, Achmad. "Hukum Perkawinan Beda Agama", Info Singkat Kesejahteraan Sosial, Vol. VI, No. 23/I/P3DI/Desember/2014, 11-12.

Nurcholish, Ahmad. "Interfaith Marriage in The Constitution and The Islamic Law Dinamics in Indonesia," Al-Mawarid Journal of Islamic Law, Vol. XV, No.1 (August 2015): 130-141.

Purwaharsanto, FXS. Perkawinan Campuran Antar Agama Menurut UU RI No. 1 Tahun 1974 tentang Perkawinan: Sebuah Telaah Kritis. Yogyakarta: Aktualita Media Cetak, 1992.

Rahman, Fazlur. "A Survey of Modernization of Muslim Family Law," International Journl of Middle East Studies, Vol. 11, Issue 4, (July 1980): 451-465.

Sedgwick, Mark. Islam \& Muslims: a Guide to Diverse Experience in a Modern World. London: Intercultural Press, 2006.

Sjadzali, Munawir. Islam dan Tata Negara. Jakarta: UI Press, 1993.

Subekti. Law in Indonesia. Jakarta: Gunung Agung, 1973. 
Tirimanna, Fr. Vimal. "A Few Theological and Pastoral Perspectives of Inter-Faith Marriages," FABC Papers No. 127.

Tjay Ing, Hs. Tjhie. Hak Asasi Beragama dan Perkawinan Khonghucu. Jakarta: Gramedia Pustaka Umum \& MATAKIN, 1998.

Trisnaningsih, Mudiarti. Relevansi Kepastian Hukum dalam Mengatur Perkawinan Beda Agama di Indonesia. Bandung, 2007.

Widyawati. "Interreligious Marriage In The Kompilasi Hukum Islam: A Human Right Perspective," Advances in Natural and Applied Sciences, 6(6): 2012, 858-865.

Rosdiana, Ummu Hanah Yusuf Saumin, \& Masayu Mashita Maisarah, Faculty of Sharia and Law, UIN Syarif Hidayatullah Jakarta, Jalan Raya H. Djuanda No. 95 Tangerang Selatan 